\author{
dr Barbara Budyńska \\ Biblioteka Narodowa \\ Instytut Książki i Czytelnictwa \\ Pracownia Bibliotekoznawstwa \\ b.budynska@bn.org.pl
}

\title{
ROLA DOTACJI BUDŻETOWYCH I POZABUDŻETOWYCH W DZIAŁALNOŚCI BIBLIOTEK PUBLICZNYCH
}

\author{
THE ROLE OF THE STATE BUDGET AND OTHER SUBSIDIES \\ IN THE ACTIVITY OF THE PUBLIC LIBRARIES
}

\begin{abstract}
Abstrakt
Zmiana zasad finansowania bibliotek publicznych umożliwiła obok dotowania budżetowego (organizatora) dotowanie pozabudżetowe poprzez granty, projekty pozyskane ze środków finansowych z przeznaczeniem na konkretny cel. Dotowanie pozabudżetowe ma najczęściej charakter okazjonalny, dotyczy konkretnej sfery działalności bibliotek. W ostatnich latach zwiększyła się liczba instytucji współpracujących z bibliotekami, co nie tylko wpłynęło na poprawę ich kondycji, ale wzbogaciło kontakty z różnymi niebibliotekarskimi instytucjami, fundacjami, stowarzyszeniami, ożywiło relacje środowiskowe, wpłynęło na zmianę wizerunku bibliotek. Programy Ministra Kultury i Dziedzictwa Narodowego skierowane do bibliotek publicznych mają charakter celowych dotacji pozabudżetowych.
\end{abstract}

Słowa kluczowe: biblioteki publiczne, finansowanie bibliotek publicznych, dotacje celowe.

\begin{abstract}
With the new rules on library funding, the libraries can now be financed both from the state budget (by the managing authority) and from the other sources such as the subsidies, grants and projects that enable to obtain funds for specific purposes. This extra-budgetary funding is typically occasional
\end{abstract}


and related to a particular area of activity. In the recent years, the number of entities working with the libraries has increased, which not only improved their condition, but also ramped up their networking with other institutions, foundations, and associations as well as enhanced the outreach of libraries' community and revamped their public image. The programmes of the Ministry of Culture and National Heritage for public libraries provide targeted extra-budgetary subsidies. Offered under the ministry or government programmes, they guarantee that public libraries receive additional funds over several years, with the managing authority, i.e. the local government, also being involved, as it is required to make its own contribution to the programmes as well.

Keywords: public libraries, public library funding, targeted subsidies, government programmes.

\section{Wprowadzenie}

Zmiany społeczne, jakie zaszły w Polsce po 1989 r. w zasadniczy sposób wpłynęły na sytuację bibliotek, w szczególności bibliotek publicznych. W wyniku wprowadzonych w latach 90. reform ustrojowych ${ }^{1}$ organizatorami bibliotek publicznych stały się samorządy na poziomie gminy ${ }^{2}$ od 1990 r., powiatu ${ }^{3}$ i województwa ${ }^{4}$ od 1999 r. Bibliotekom publicznym przypisano też szczególny status. Stały się samodzielnymi instytucjami kultury ${ }^{5}$, mającymi osobowość prawną, prowadzącymi samo-

1 Ustawa $z$ dnia 17 maja 1990 r. o podziale zadań i kompetencji określonych $w$ ustawach szczególnych pomiędzy organy gminy a organy administracji rządowej oraz o zmianie niektórych ustaw. Dz.U. 1990, nr 34, poz. 198; Ustawa z dnia 24 lipca 1998 r. o zmianie niektórych ustaw określających kompetencje organów administracji publicznejw związku z reforma ustrojowa państwa. Dz.U. 1998, nr 106, poz. 668; Ustawa z dnia 13 października 1998 r. Przepisy wprowadzajace ustawy reformujące administracje publiczna. Dz.U. 1998, nr 133, poz. 872.

2 Ustawa z dnia 8 marca 1990 r. o samorzadzie gminnym. Dz.U. 1990, nr 16, poz. 95, z późn. zm.

3 Ustawa $z$ dnia 5 czerwca 1998 r. o samorzadzie powiatowym. Dz.U. 1998, nr 91, poz. 578.

4 Ustawa z dnia 5 czerwca 1998 r. o samorządzie województwa Dz.U. 1998, nr 91, poz. 576.

5 Ustawa z dnia 25 października 1991 r. o organizowaniu i prowadzeniu działalności kulturalnej. Dz.U. 1997, nr 110, poz. 721 z późn. zm.; Ustawa z dnia 27 sierpnia 2009 r. o finansach publicznych. Dz.U. 2009, nr 157, poz. 1240; brzmienie od 1 stycznia 2014 r.: Obwieszczenie Marszałka Sejmu Rzeczypospolitej Polskiej z dnia 21 czerwca 
dzielną politykę finansową, instytucjami stanowiącymi o swoim funkcjonowaniu ( $\mathrm{w}$ ścisłym porozumieniu $\mathrm{z}$ organizatorem), $\mathrm{z}$ wyjątkiem bibliotek włączonych w struktury innych instytucji ${ }^{6}$, bądź - niezgodnie z prawem - zorganizowanych jako jednostki budżetowe gminy. Podkreślono w ten sposób charakter bibliotek publicznych, silny związek ze środowiskiem, w których działają, a także możliwość reagowania na społeczne oczekiwania. Uwieńczeniem tego szczególnego statusu bibliotek publicznych jest obowiązek ich wpisu w lokalne rejestry instytucji kultury.

Podstawową zmianą w funkcjonowaniu bibliotek publicznych wynikającą z usamorządowienia jest sposób finansowania. Ich przychody składają się przede wszystkim $\mathrm{z}$ dotacji budżetowych (organizatora) oraz $\mathrm{z}$ dotacji pozabudżetowych, płynących $\mathrm{z}$ różnych źródeł i w różnej formie (środki pieniężnie, dary rzeczowe - materiały, urządzenia, nieodpłatne świadczenie usług), a także $\mathrm{z}$ dochodów $\mathrm{z}$ własnej działalności i innych wpływów, choć na ogół stanowią one znikomą część całości.

Zorganizowanie bibliotek publicznych jako instytucji kultury w myśl zapisów Ustawy o organizowaniu i prowadzeniu działalności kulturalnej ${ }^{7}$ oraz instytucji samorządowych $\mathrm{w}$ odniesieniu do zapisów ustaw samorządowych $^{8}$ daje im duże możliwości, ale również stwarza ograniczenia. Biblioteki publiczne prowadzą coraz szerszą i różnorodną działalność (np.: czytelniczą, upowszechnieniową, animacyjną), co sprzyja inwencji i kreatywności bibliotekarzy, nawiązywaniu partnerstw, środowiskowej, jak i ponadlokalnej współpracy. Obecne możliwości bibliotek publicznych sprzyjają także ich rozwojowi jako samodzielnych instytucji poprzez stosowanie przez nie różnorodnych form działania, udziałowi w przedsięwzięciach o niestandardowym charakterze. Z drugiej strony, aktywność bibliotek zwiększa zainteresowanie nimi różnych podmiotów (organizacji i stowarzyszeń pozarządowych - krajowych i międzynarodowych, instytucji, firm i korporacji), które coraz liczniej oferują: programy, projekty, granty wspierające rozwój zarówno bibliotek i bibliotekarzy, promujące usługi, czytelnictwo, umożliwiające wdrażanie nowych technologii poprzez

2013 r. w sprawie ogłoszenia jednolitego tekstu ustawy o finansach publicznych, Dz.U. 2013, poz. 885.

6 Ustawa $z$ dnia 31 sierpnia 2011 r. o zmianie ustawy o organizowaniu i prowadzeniu działalności kulturalnej. Dz.U. 2011, nr 207, poz. 1230. Zapisy obowiązują od 1 października 2012 r.

7 Ustawa z dnia 25 października 1991 r. o organizowaniu i prowadzeniu działalności kulturalnej, dz. cyt., rozdz. 2.

8 Ustawa z dnia 8 marca 1990 r. o samorządzie gminnymi, dz. cyt., art. 7.1 ust. 1. 
wyposażanie w sprzęt, programy biblioteczne. Mimo szeroko rozumianej samodzielności biblioteki publiczne odczuwają silny wpływ środowiska na swoją kondycję i możliwości działania. Choć efekty są odmienne, tak jest w przypadku gmin o dużym potencjale ekonomicznym i możliwościach wspierania swych lokalnych instytucji oraz środowisk o niskich dochodach, często naznaczonych problemami społecznymi, które mimo doceniania pracy bibliotek, nie mogą ich finansować na odpowiednim poziomie. Dodatkowym czynnikiem stanowiącym o sytuacji bibliotek publicznych jest ocena ich działalności poprzez pryzmat rozumienia specyfiki pracy bibliotek, społecznego myślenia o lokalnych instytucjach, dbałości o rozwój dla środowiska. Wymienione czynniki sprawiają, iż pogłębiają się dysproporcje między bibliotekami publicznymi funkcjonującymi w odmiennych warunkach. Biblioteki pracujące $\mathrm{w}$ środowiskach o dużym potencjale na ogół dysponują także większym bagażem zawodowych doświadczeń wynikających z udziału w ogólnopolskich programach, np. w Programie Rozwoju Bibliotek9.

\section{Finansowanie bibliotek publicznych}

Kondycja bibliotek publicznych, ich możliwości, a także rozwój w zasadniczym stopniu uzależnione są od finansowania, tzn.:

- finansowania podmiotowego (dotacji budżetowej organizatora);

- finansowania pozapodmiotowego (dotacji pozabudżetowych/ /celowych np. pochodzących od innych podmiotów niż organizator).

Podstawą finansowania bibliotek publicznych jest dotacja podmiotowa organizatora. Według danych GUS za 2015 r. dotacja organizatora ma największy udział w przychodach bibliotek pedagogicznych, dotacje celowe najczęściej pozyskują biblioteki naukowe, zaś najmniej wpływów z działalności własnej mają biblioteki publiczne, z pozostałych źródeł - biblioteki pedagogiczne.

Dotacja organizatora, stanowiąca zasadniczą cześć budżetów bibliotek publicznych jest obligatoryjna (Ustawa o bibliotekach reguluje, jakie koszty ponosi organizator ${ }^{10}$ ), planowana, choć $\mathrm{w}$ trakcie roku budżetowego może

9 Program Rozwoju Bibliotek - FRSI (PRB) prowadzony był w trzech rundach w latach 2009-2015. Skierowany do bibliotek publicznych w środowiskach do 20 tys. mieszkańców objął 3808 bibliotek z 1256 gmin z budżetem 101,8 mln zł.

10 Ustawa z dnia 27 czerwca 1997 r. o bibliotekach (tekst jednolity Dz.U. 1997, nr 87, poz. 642 , art. 9 ust. 2). 
ulec zmniejszeniu lub zwiększeniu, np. w zakresie środków na zakup nowości. Pomimo, iż udział środków zewnętrznych w przychodach bibliotek publicznych nie jest wysoki, mają one ogromny wpływ na ich działalność. $Z$ funduszy tych finansowany jest np.: zakup nowości wydawniczych, szkolenia podnoszące kompetencje zawodowe bibliotekarzy, imprezy kulturalne i inicjatywy edukacyjne, zaopatrzenie w komputery i nowe technologie, dostęp do Internetu, prowadzanie usług cyfrowych. Uczestnictwo w projektach wiąże się z wieloma korzyściami dla bibliotek publicznych, dzięki nim: rozwijają kolekcje i usługi, modernizują i unowocześniają swe placówki, wyposażają w sprzęt, mają dostęp do baz informacyjnych, wzbogacają ofertę kulturalną, a także sprzyjają integracji bibliotek w obrębie sieci lokalnych i regionalnych.

Dotacje pozabudżetowe mogą mieć również charakter wieloletni, np. przekazywane poprzez programy resortowe lub rządowe, gwarantujące bibliotekom publicznym dodatkowe środki na zadania celowe $\mathrm{w}$ perspektywie kilku/kilkunastu lat, $\mathrm{z}$ jednoczesnym zaangażowaniem organizatora-samorządu, który musi wnieść wkład własny. Jednak dotowanie pozabudżetowe płynące $\mathrm{z}$ różnych instytucji, pozarządowych czy lokalnych sponsorów ma głównie charakter okazjonalny, dotyczy konkretnej sfery działalności bibliotek, przybiera różne formy, na ogół nie angażuje środków organizatora. W ostatnich latach zwiększyła się liczba instytucji współpracujących z bibliotekami publicznymi, co nie tylko wpłynęło na poprawę ich kondycji, ale co ważne w kontekście środowiskowego charakteru ich działalności, wzbogaciło kontakty $\mathrm{z}$ instytucjami niebibliotekarskimi, fundacjami, stowarzyszeniami, ożywiło relacje lokalne, wpłynęło na wizerunek bibliotek.

Biblioteki publiczne dotowane są ze środków pozabudżetowych w różny sposób, różna jest też ranga przekazywanych dotacji. Szczególne znaczenie mają programy rządowe (np. Rządowy Program na rzecz Aktywności Społecznej Osób Starszych na lata 2014-2020, Wieloletni Program Narodowy Program Rozwoju Czytelnictwa 2016-2020, Program Wieloletni Kultura+) i resortowe (np. programy MKiDN, MSWiA - komputeryzacja bibliotek Ikonka 2004, Ikonka 2007, MAiC i Ministerstwa Infrastruktury i Rozwoju - Program Operacyjny Polska Cyfrowa 2014-2020). Ich przygotowanie i wdrożenie oparte jest na rzetelnych podstawach, są elementem polityki kulturalnej państwa ${ }^{11}$, ich realizacja objęta jest programem inicjatyw

11 Kultura a rozwój. Red. J. Hausner, A. Karwińska, J. Purchla. Warszawa 2013; B. Budyńska, M. Jezierska: Polityka biblioteczna i finansowanie bibliotek publicznych $w$ Polsce. 
o szerokim zasięgu społecznym ${ }^{12}$. Charakteryzuje je stałość i poziom finansowania, realizacja $\mathrm{w}$ postaci wieloletnich programów obejmujących np.: wzbogacanie kolekcji bibliotecznych, poprawa infrastruktury, podnoszenie kompetencji bibliotekarzy, wprowadzanie nowych technologii, rozwój form pracy. Przygotowanie programów opiera się na wszechstronnej diagnozie sytuacji bibliotek w Polsce, analizie wskaźników dotyczących podstawowych parametrów ich pracy $^{13}$. Punktem odniesienia są zalecane standardy (np. IFLA), normy dotyczące podstawowych funkcjonalności bibliotek wdrażane w innych krajach (np. skandynawskich). Analizowane są również inicjatywy, których celem, podobnie jak w Polsce, jest wzrost potencjału bibliotek i rozwój ich działalności (np.: Estonia, Portugalia, Hiszpania). Jeśli chodzi o warunki polskie punktem odniesienia dla opracowywanych programów dla bibliotek publicznych były np. analizy funkcjonowania bibliotek ${ }^{14} \mathrm{i}$ parametry dla bibliotek publicznych ujęte np. w Certyfikacie Biblioteka $+{ }^{15}$.

Coraz większego znaczenia $\mathrm{w}$ finansowaniu pozabudżetowym bibliotek publicznych nabierają granty, dotacje, programy oferowane przez stowarzyszenia i fundacje. Mają one różny charakter, podobnie różny jest poziom ich finansowania - od doraźnych akcji, imprez i programów po ofertę o zasięgu ogólnopolskim, wieloletnim, wysoko budżetowym. Na przykład Fundacja ABC XXI od 2001 r. prowadzi działania wspierające czytelnictwo, realizuje projekty: Cała Polska czyta dzieciom, Pierwsza książka mojego dziecka, Czytające przedszkola, Czytające szkoły;

„Kultura Współczesna” 2012, nr 2, s. 122-137.

$12 \mathrm{Na}$ przykład ideą Strategii Rozwoju Kapitału Społecznego jest wsparcie czytelnictwa, jako najważniejszego z elementów kapitału społecznego. Dokument ten był podstawą do sformułowania założeń Wieloletniego Programu Narodowego Programu Rozwoju Czytelnictwa, którego celem jest m.in. poprawa warunków pracy bibliotek, w tym bibliotek publicznych oraz wzbogacanie ich księgozbiorów. Uchwała Nr 61 Rady Ministrów $z$ dnia 26 marca 2013 r. w sprawie przyjęcia Strategii Rozwoju Kapitału Społecznego 2020. Tryb dostępu: http://:isip.sejm.gov.pl/Download?id=WMP20130000378\&type=2 [14 lipca 2017].

13 Program Wieloletni Narodowy Program Rozwoju Czytelnictwa, s. 5-30. Tryb dostępu: http://bip.mkidn.gov.pl/media/download_gallery/20150618_zalacznik_do_projektu_ uchwaly.pdf [14 lipca 2017].

14 B. Budyńska, M. Jezierska, G. Lewandowicz-Nosal, G. Walczewska-Klimczak: Biblioteki w Polsce w 2012 r. Warszawa 2016. Tryb dostępu: http://ksiegarnia.bn.org.pl/396/ Biblioteki-w-Polsce-w-2012-roku.html [29 marca 2017]; Biblioteki Publiczne w Liczbach za lata 2000-2011. Warszawa 2001-2015; Stan bibliotek w Polsce. Raport 2012. Warszawa 2016.

15 B. Budyńska, M. Jezierska: Zbiory w bibliotekach publicznych a ich finansowanie (maszynopis). 
Fundacja Rozwoju Społeczeństwa Informacyjnego w latach 2009-2015 realizowała Program Rozwoju Bibliotek z budżetem 101,8 mln zł; Centrum Edukacji Obywatelskiej od 2015 r. inicjuje akcję Noc Bibliotek ${ }^{16}$, Stowarzyszenie Bibliotekarzy Polskich od 2004 r. prowadzi program Tydzień Bibliotek. Organizacjami, które tworzyły specjalne programy wspierania bibliotek były także m.in.: Fundacja na Rzecz Nauki Polskiej, Fundacja Batorego, Fundacja Bertelsmanna, Fundacja Współpracy Polsko-Niemieckiej, Polskie Stowarzyszenie Pedagogów i Animatorów KLANZA, Fundacja im. M. Oczapowskiego, Fundacja Rozwoju Systemu Edukacji, Fundacja Dzieci Niczyje, Towarzystwo Inicjatyw Twórczych „ę", Fundacja Wspomagania Wsi, Fundacja Rozwoju Dzieci im. Jana Amosa Komenskiego, Fundacja Bankowa im. Leopolda Kronenberga, Fundacja Wspomagania Wsi, Stowarzyszenie Gmin Polskich - Euroregion „Pradziad”, Fundacja Orange.

Tabela 1. Finansowanie budżetowe i pozabudżetowe bibliotek w Polsce w \% w 2015 r. $^{17}$

\begin{tabular}{|l|c|c|c|c|}
\hline \multirow{2}{*}{ Źródła finansowania } & \multirow{2}{*}{ Ogółem } & \multicolumn{3}{|c|}{ Biblioteki } \\
\cline { 3 - 5 } & & publiczne & pedagogiczne & naukowe \\
\hline Dotacja budżetowa & 91 & 92,2 & 97,8 & 87,4 \\
\hline Dotacja pozabudżetowa & 5,2 & 4 & 0,6 & 7,9 \\
\hline Środki wypracowane & 2,2 & 2 & 2,5 & 3 \\
\hline Pozostałe wpływy & 1,5 & 1,8 & 0,1 & 1,8 \\
\hline
\end{tabular}

Zródło: opracowanie własne na podstawie danych GUS.

Ważne znaczenie w finansowaniu bibliotek publicznych mają środki zagraniczne, w tym unijne, m.in. fundusze: Open Society w Budapeszcie, Bosch Stiftung w Niemczech, Mellon Foundation w USA, a także Norweski Mechanizm Finansowy oraz Mechanizm Finansowy Europejskiego Obszaru Gospodarczego, Szwajcarsko-Polski Program Współpracy, Międzynarodowy Fundusz Wyszehradzki.

Do katalogu możliwości dofinansowania bibliotek publicznych dołączyć należy pozabudżetowe fundusze pozyskiwane $\mathrm{w}$ postaci dotacji samorządów różnych szczebli, np.: urzędów marszałkowskich, samorządu

16 Współorganizatorami Nocy Bibliotek są: „Gazeta Wyborcza” i Magazyn „Książki”, Instytut Książki, Fundacja „ABCXXI - Cała Polska czyta dzieciom”, FRSI.

$17 \mathrm{~W}$ artykule wykorzystano dane liczbowe z różnych źródeł: z GUS dotyczą okresu do 2015 r., ze sprawozdań wbp - do 2016 r., z założeń programów do 2020 r. 
powiatowego, miejskiego oraz środki od lokalnych sponsorów, np. Lokalnych Grup Działania ${ }^{18}$.

Tabela 2. Dotacje MKiDN na zakup nowości wydawniczych w latach 2000-2017 - wysokość, forma i kryteria przekazania bibliotekom

\begin{tabular}{|c|c|c|c|}
\hline Lata & $\begin{array}{c}\text { Wysokość } \\
\text { dotacji (w zl) }\end{array}$ & $\begin{array}{c}\text { Forma } \\
\text { przekazania }\end{array}$ & Kryteria \\
\hline 2000 & 9000000 & dar & $\begin{array}{l}\text { procentowy udział wydatków na zakup } \\
\text { książek w województwach w stosunku } \\
\text { do ogółu wydatków w } 1999 \text { r. }\end{array}$ \\
\hline 2001 & 7463000 & depozyt & liczba czytelników \\
\hline 2002 & 1150000 & depozyt & liczba czytelników \\
\hline 2003 & 5000000 & depozyt & $\begin{array}{l}\text { o kryteriach decydowały wbp (liczba } \\
\text { czytelników, zakup nowości) }\end{array}$ \\
\hline 2004 & 10000000 & $\begin{array}{l}\text { porozumienia } \\
\text { z samorządami }\end{array}$ & liczba czytelników \\
\hline 2005 & 30000000 & $\begin{array}{l}\text { porozumienia } \\
\text { z samorządami }\end{array}$ & $\begin{array}{l}\text { liczba ludności, liczba czytelników, } \\
\text { PKB na } 1 \text { mieszkańca }\end{array}$ \\
\hline $\begin{array}{l}2006- \\
-2008\end{array}$ & 28500000 & $\begin{array}{l}\text { umowy } \\
\text { z bibliotekami }\end{array}$ & $\begin{array}{l}\text { liczba ludności, liczba czytelników, } \\
\text { PKB na } 1 \text { mieszkańca (w } 2006 \text { r. docho- } \\
\text { dy do dyspozycji brutto w gospodar- } \\
\text { stwach domowych na } 1 \text { mieszkańca) }\end{array}$ \\
\hline $\begin{array}{l}2009- \\
-2010\end{array}$ & 10000000 & $\begin{array}{l}\text { umowy } \\
\text { z bibliotekami }\end{array}$ & $\begin{array}{l}\text { liczba ludności, liczba czytelników, } \\
\text { PKB na } 1 \text { mieszkańca }\end{array}$ \\
\hline 2011 & 15000000 & $\begin{array}{l}\text { umowy } \\
\text { z bibliotekami }\end{array}$ & $\begin{array}{l}\text { liczba ludności, liczba czytelników, } \\
\text { PKB na } 1 \text { mieszkańca }\end{array}$ \\
\hline $\begin{array}{l}2012- \\
-2013\end{array}$ & 20000000 & $\begin{array}{l}\text { umowy } \\
\text { z bibliotekami }\end{array}$ & liczba ludności, liczba czytelników \\
\hline 2014 & $\begin{array}{l}\text { Priorytet }-1 \\
200000000 \\
\text { Priorytet }-2 \\
3000000\end{array}$ & $\begin{array}{l}\text { umowy } \\
\text { z bibliotekami }\end{array}$ & $\begin{array}{l}\text { liczba ludności, liczba czytelników } \\
\text { partnerstwo z bibliotekami szkolnymi }\end{array}$ \\
\hline 2015 & 25000000 & $\begin{array}{l}\text { umowy } \\
\text { z bibliotekami }\end{array}$ & liczba ludności, liczba czytelników \\
\hline $\begin{array}{l}2016- \\
-2017\end{array}$ & 26500000 & $\begin{array}{l}\text { umowy } \\
\text { z bibliotekami }\end{array}$ & liczba ludności, liczba czytelników \\
\hline
\end{tabular}

Źródło: opracowanie własne.

$18 \mathrm{O}$ zasięgu działania lokalnych instytucji na rzecz bibliotek publicznych mówią sprawozdania merytoryczne wojewódzkich bibliotek publicznych przygotowywane co roku dla MKiDN. 


\section{Programy resortowe i rządowe skierowane do bibliotek publicznych}

Spośród wielu inicjatyw dotowania pozabudżetowego bibliotek publicznych na szczególną uwagę, ze względu na rangę i rolę przedsięwzięcia, zasługują resortowe i rządowe programy wspierające unowocześnianie księgozbiorów bibliotecznych - zakup nowości wydawniczych. Trwają one od 2000 r. w ramach doraźnych programów MKiDN; od 2004 r. jako program resortowy o charakterze stałym, który ewoluował do 2016 r., kiedy stał się programem realizowanym jako program wieloletni rządowy. W okresie tym mimo iż zmieniały się zasady i kryteria realizacji programów oraz przyznawania dotacji wymogi stawiane bibliotekom i organizatorom, cel pozostawał ten sam - wzbogacenie księgozbiorów bibliotek, zwiększanie atrakcyjności ofert bibliotek poprzez stały, systematyczny dopływ nowości bibliotecznych, wzrost dostępności książek czasopism, multimediów, wydawnictw nutowych i kartograficznych, a także czytelnictwa wśród Polaków.

Tabela 3. Czytelnicy w bibliotekach publicznych

\begin{tabular}{|c|c|c|c|c|}
\hline \multirow{2}{*}{ Lata } & \multicolumn{4}{|c|}{ Liczba czytelników } \\
\cline { 2 - 5 } & \multirow{2}{*}{ ogółem } & \multirow{2}{*}{$\begin{array}{c}\text { na 100 } \\
\text { mieszkańców }\end{array}$} & \multicolumn{2}{|c|}{ w tym wieś } \\
\cline { 4 - 5 } & & 19,1 & 1912728 & \% ogółu \\
\hline 2000 & 7391555 & 19,2 & 1887854 & 25,9 \\
\hline 2005 & 7337277 & 17 & 1657985 & 25,5 \\
\hline 2010 & 6501933 & 16,2 & 1599436 & 25,7 \\
\hline 2015 & 6232907 & &
\end{tabular}

Zródło: Biblioteki Publiczne w Liczbach. Oprac. Biblioteka Nardowa (BN).

Realizacja programu zakup nowości do bibliotek publicznych wiąże się z niestabilną ich sytuacją wynikającą m.in. z usamorządowienia, tj. przekazania kompetencji w zakresie ich finansowania organizatorom. Ograniczenia wydatków samorządowych na działalność podstawową najbardziej niekorzystnie wpłynęło na zakup książek do bibliotek, w efekcie czego, w bardzo krótkim czasie nie tylko spadły wskaźniki zakupu do bibliotek publicznych, ale również drastycznie obniżyły się wskaźniki zasięgu czytelnictwa. 


\section{Etapy rozwoju programu zakup nowości do bibliotek}

1. Narodowy Program Kultury Promocja Czytelnictwa i Rozwój Sektora Książki był jednym z pięciu narodowych programów kultury (obok programów: Ochrona Zabytków i Dziedzictwa Kulturowego, Rozwój Instytucji Artystycznych, Rozwój sztuki współczesnej i muzea nowoczesności, Znaki Czasu oraz Wspieranie Debiutów i Rozwój Artystycznych Szkót Wyższych Maestria) ujętych w Narodowej Strategii Rozwoju Kultury na lata 2004-2013, która wyznaczyła nowe zadania resortu kultury w zakresie współpracy z samorządami terytorialnymi, a także zasady wykorzystania środków funduszy strukturalnych i innych funduszy europejskich w kulturze.

Narodowy Program Kultury Promocja Czytelnictwa i Rozwój Sektora na lata 2004-2013 ${ }^{19}$ zakładał m.in.: poprawę warunków funkcjonowania bibliotek i dostępności do usług bibliotecznych, wzrost jakości zbiorów, zwiększenie roli czytelnictwa w wychowaniu i edukacji. W 2011 r. z inicjatywy MKiDN został uchwalony na lata 2011-2015 rządowy Program Wieloletni Kultura+, który stanowił dopełnienie programu dotującego zakup nowości, zakładał m.in. modernizację infrastruktury bibliotek na terenach wiejskich i miejsko-wiejskich, jak również digitalizację i udostępnianie zbiorów.

W obrębie Narodowego Programu Kultury Promocja Czytelnictwa i Rozwój Sektora Książki w latach 2004-2015 realizowano program Zakup nowości wydawniczych do bibliotek z budżetem 153,5 mln zł oraz Wieloletni Program Kultura+ obejmujący priorytet I Infrastruktura bibliotek (budżet $150 \mathrm{mln}$ zł) oraz priorytet II Digitalizacja zbiorów bibliotecznych (budżet $120 \mathrm{mln} \mathrm{zl})$.

2. Narodowy Program Rozwoju Czytelnictwa 2014-202020 został opracowany zgodnie z zapisami Paktu dla Kultury oraz Strategii Rozwoju Kapitału Społecznego $2020^{21}$. Istotnym elementem Programu były działania zmieniające i wzmacniające rolę biblioteki jako podstawowej przestrzeni kontaktu z książką (np.: w zakresie zakupu nowości do bibliotek, budowy i modernizacji budynków bibliotek, unowocześniania serwisu bibliotecznego, stworzenia i rozwoju jednolitego, ogólnopolskiego, centralnego systemu

19 Narodowy Program Kultury. Promocja Czytelnictwa $i$ Rozwój Sektora na lata 2004-2013. Tryb dostępu: http://bip.mkidn.gov.pl/media/docs/NPK_Czytelnictwo.pdf [14 lipca 2017].

20 Narodowy Program Rozwoju Czytelnictwa 2014-2020. Tryb dostępu: http://www. mkidn.gov.pl/media/docs/2013/20131220__NPRCZ.pdf [14 lipca 2017].

21 Uchwała Nr 61 Rady Ministrów z dnia 26 marca 2013 r., dz. cyt. 
komputerowego MAK+ umożliwiającego zarządzanie zbiorami bibliotecznymi, wymianę informacji o księgozbiorach i wypożyczeniach pomiędzy samymi bibliotekami oraz zdalny dostęp poprzez Internet dla czytelników, internetyzację bibliotek, szkolenie bibliotekarzy w zakresie nowych kompetencji). W ramach Programu realizowano m.in. podprogramy: Zakup nowości wydawniczych do bibliotek, Promocje literatury i czytelnictwa, Program szkoleń dla bibliotekarzy, Dyskusyjne Kluby Książki, MAK+, Kraszewski. Komputery dla bibliotek, kontynuowano tworzenie Korpusu Publikacji Polskich (opisów katalogowych publikacji wydanych w Polsce, m.in.: książek, czasopism, map oraz płyt CD i DVD z muzyką i filmami, a także audiobooków), co pozwoliło na ujednolicenie opisów wszystkich typów publikacji w bibliotekach krajowych i na szybkie wprowadzenie katalogów internetowych bibliotek w Polsce. Planowano, iż budżet Narodowego Programu Rozwoju Czytelnictwa 2014-2020 wyniesie $1 \mathrm{mld}$ zł (650 mln zł ze środków MKiDN i 350 mln zł m.in. od samorządów i instytucji).

3. Program Wieloletni Narodowy Program Rozwoju Czytelnictwa 2016$-2020^{22}$ przyjęty został przez Ministerstwo Kultury i Dziedzictwa Narodowego oraz Ministerstwo Edukacji Narodowej na podstawie postanowień Strategii Rozwoju Kraju 2020 23 oraz Strategii Rozwoju Kapitału Społecznego 2020, które zakładają wsparcie czytelnictwa jako jednego z najważniejszych elementów kapitału kulturowego. Program Wieloletni skupia się na podniesieniu standardów infrastrukturalnych i zaktywizowaniu bibliotek publicznych, szkolnych i pedagogicznych, które są ważnym źródłem książek dla czytelników i wpływają na poziom czytelnictwa. Jego realizacja pozwoli na ułatwienie dostępu do książek wszystkim użytkownikom dzięki wzbogacaniu i urozmaicaniu księgozbiorów bibliotecznych. Kolejnym celem programu jest stworzenie sieci zmodernizowanych i nowoczesnych bibliotek publicznych $\mathrm{w}$ gminach wiejskich, wiejsko-miejskich i miejskich do 50 tys. mieszkańców.

Program Wieloletni został podzielony na trzy priorytety.

Priorytet I Zakup nowości wydawniczych do bibliotek publicznych, którego operatorem jest Biblioteka Narodowa ma na celu zwiększenie oferty bibliotek publicznych o nowe książki i multimedia przez stałe doposażenie bibliotek i aktualizowanie ich zasobów. Priorytet uwzględnia zakres dotychczas

22 Tamże.

23 Uchwała nr 157 Rady Ministrów z dnia 25 września 2012 r. w sprawie przyjęcia Strategii Rozwoju Kraju 2020. M.P. 2012, poz. 882. 
istniejącego programu BN Zakupów nowości wydawniczych do bibliotek (135 mln zł w ciągu 5 lat).

Priorytet II Infrastruktura Bibliotek 2016-2020, którego operatorem jest Instytut Książki ma na celu wzmocnienie potencjału i roli gminnych bibliotek publicznych poprzez finansowe wsparcie modernizacji, budowy lub przebudowy placówek bibliotecznych, jako miejsc kreowania kapitału społecznego i kulturowego, zwłaszcza w mniejszych miejscowościach. Priorytet stanowi kontynuację rozwiązań realizowanych poprzez Program Wieloletni Kultura+, priorytet Biblioteka+ Infrastruktura Bibliotek, zakończony w 2015 r. W efekcie ma podnieść jakość i standardy działania bibliotek, poprawić warunki lokalowe, wyposażenie bibliotek publicznych oraz przekształcić je w nowoczesne centra dostępu do wiedzy, kultury oraz ośrodki życia społecznego (150 mln zł w ciągu 5 lat).

Priorytet III Rozwijanie zainteresowań uczniów przez promowanie i wspieranie rozwoju czytelnictwa wśród dzieci i młodzieży, w tym zakup nowości wydawniczych ma na celu upowszechnianie edukacji czytelniczej i medialnej oraz wzrost czytelnictwa wśród uczniów. Operatorem Priorytetu na szczeblu wojewódzkim jest wojewoda. W efekcie działań przewidzianych w priorytecie III podniesiony zostanie standard usług i jakość pracy bibliotek szkolnych i pedagogicznych oraz rozbudowany zostanie księgozbiór bibliotek. Dodatkowym elementem jest wspieranie współpracy pomiędzy biblioteką szkolną a publiczną, która umożliwi szersze czerpanie korzyści z priorytetu dzieciom i młodzieży w wieku szkolnym (150 mln zł w okresie 5 lat).

\section{Zakup nowości wydawniczych do bibliotek publicznych}

Zakup nowości wydawniczych do bibliotek publicznych to program rządowy skierowany od 2004 r. do bibliotek publicznych, który od 2016 r. funkcjonuje jako program wieloletni rządowy. W czasie jego trwania zmieniał się operator programu. Do 2009 r. był on w gestii Resortu Kultury, od 2010 r. zarządza nim Biblioteka Narodowa. Ewolucję programu można prześledzić analizując jego nazwy i usytuowanie w obrębie programów i priorytetów:

- 2004 - Program Operacyjny Promocja Czytelnictwa, priorytet I Rozwój księgozbiorów bibliotek;

- 2005 - Program Operacyjny Promocja Czytelnictwa, priorytet I Rozwój bibliotek oraz poprawa jakości i dostępności zbiorów, zadanie: Zakup nowości wydawniczych do bibliotek publicznych; 
- 2006-2008 - Program Operacyjny Promocja Czytelnictwa, priorytet I Rozwój księgozbiorów bibliotek, zadanie: Zakup nowości wydawniczych do bibliotek;

- 2009 - Program Ministra Kultury i Dziedzictwa Narodowego Literatura i Czytelnictwo, priorytet II Zakup nowości wydawniczych dla bibliotek;

- 2010-2015 - Program Biblioteki Narodowej Zakup nowości wydawniczych do bibliotek;

- 2016-2020 - Program Wieloletni Narodowy Program Rozwoju Czytelnictwa, priorytet I Zakup nowości wydawniczych do bibliotek publicznych.

\section{Kryteria programu}

Kryteria oceny zadań i zasady rozdziału środków Programu Wieloletniego przygotowywane są i zatwierdzane przez Dyrektora Biblioteki Narodowej we współpracy z dyrektorami wojewódzkich bibliotek publicznych oraz Zespołem Sterującym, którego skład co roku powołuje Minister Kultury i Dziedzictwa Narodowego. Program jest elementem polityki bibliotecznej resortu kultury $\mathrm{w}$ zakresie kształtowania księgozbiorów bibliotek oraz wsparcia samorządów w finansowaniu zakupów nowości, a jednocześnie stworzenia klarownego systemu samorządowego finansowania zakupu nowości do bibliotek. Celem strategicznym programu jest stały wzrost czytelnictwa w Polsce, zmniejszenie różnic regionalnych w dostępie do usług bibliotecznych, poprawa warunków funkcjonowania bibliotek publicznych i zwiększenie dostępności do książek, poprawa jakości zbiorów bibliotecznych. Wśród celów szczegółowych znajdują się zapisy stwierdzające, że dotacja przeznaczona jest na zakup nowości wydawniczych dla bibliotek publicznych ze szczególnym uwzględnieniem:

- bibliotek wiejskich oraz bibliotek działających na terenach społecznie i ekonomicznie zmarginalizowanych (do 2011 r.);

- dofinansowania zakupu literatury dla dzieci i młodzieży (z przeznaczeniem 1/3 dotacji na ten cel) w latach 2012-2013;

- nawiązania współpracy między bibliotekami publicznymi i bibliotekami szkolnymi; w 2014 r. program podzielono na dwa priorytety: priorytet I miał na celu wzbogacenie i odnowienie księgozbiorów bibliotek publicznych, w tym księgozbiorów dla dzieci i młodzieży ( $\mathrm{z}$ uwzględnieniem wydzielenia 1/3 kwoty na 
ten cel), priorytet II promował współpracę bibliotek publicznych z bibliotekami szkolnymi;

- dofinansowania zakupu czasopism kulturalnych i społeczno-kulturalnych o charakterze ogólnopolskim o częstotliwości ukazywania się od miesięcznika do rocznika, przy założeniu stałego uatrakcyjniania księgozbiorów bibliotek publicznych (2015-2017).

\section{Założenia programu}

Założeniem programu jest dotowanie wyłącznie bibliotek publicznych zorganizowanych $\mathrm{w}$ formie instytucji kultury lub będących w strukturze instytucji kultury, np. domu kultury. Dotacja na zakup nowości wydawniczych jest ścisłe powiązana z wkładem własnym organizatora, tzn. warunkiem otrzymania dotacji jest wkład własny organizatora określony przez kryteria programu. Od 2016 r. ustalono stopniowanie wysokości minimalnego wymaganego wkładu własnego beneficjentów w zależności od zaszeregowania gminy, powiatu, województwa do odpowiedniej kategorii zamożności. Jako podstawę wyliczenia dochodów przyjmuje się dane ze sprawozdań publikowane na stronie Ministerstwa Finansów ${ }^{24}$.

Tabela 4. Zasady przydziału dotacji na zakup nowości wydawniczych

\begin{tabular}{|c|c|c|c|}
\hline Lata & $\begin{array}{c}\text { Wielkość dotacji } \\
(\mathbf{w} \text { zl) }\end{array}$ & $\begin{array}{c}\text { Kwota } \\
\min (w \mathrm{zl})\end{array}$ & Wkład własny \\
\hline 2005-2008 & $28,5 \mathrm{mln}-30 \mathrm{mln}$ & 1500 & nie mniej niż 10\% całości zadania \\
\hline 2010-2011 & $10 \mathrm{mln}$ & 700 & nie mniej niż 25\% \\
\hline $2012-2014$ & $20 \mathrm{mln}$ & $1000-1500$ & nie mniej niż 25\% \\
\hline $2015-2107$ & $25-\mathrm{mln}-26,5 \mathrm{mln}$ & 1500 & $\begin{array}{l}2015 \text { r. - nie mniej niż 25\% } \\
2016 \text { r.: I - 30\%; II - 35\%; III - 40\% } \\
2017 \text { r.: I - 30\%; II - 40\%; III - 50\% }\end{array}$ \\
\hline 2018 & $26,5 \mathrm{mln}$ & 1500 & I - 40\%; II - 50\%; III -60\% \\
\hline 2019 & $26,5 \mathrm{mln}$ & 1500 & I - 50\%; II -60\%; III- 70\% \\
\hline 2020 & $26,5 \mathrm{mln}$ & 1500 & I - 50\%; II - 65\%; III - 80\% \\
\hline
\end{tabular}

Zródło: opracowanie własne na podstawie dokumentu Wieloletni Program Narodowy

Program Rozwoju Czytelnictwa na lata 2016-2020.

24 Wyodrębniono dla każdej z kategorii samorządów (gmin, powiatów, województw) po trzy grupy zamożności: I grupa (do 60\% średnich dochodów podatkowych w kraju); II grupa (powyżej 60,01\%, ale nie i więcej niż 100\% średnich dochodów podatkowych w kraju); III grupa (powyżej 100,01\% średnich dochodów podatkowych w kraju). Na podstawie: Załącznika do Uchwały nr 180/2015 Rady Ministrów z dnia 6 października 2015 r. Program Wieloletni Narodowy Program Rozwoju Czytelnictwa, s. 85. 


\section{Kryteria podziału dotacji}

Dotacja przeznaczona na zakup nowości wydawniczych dzielona jest dwupoziomowo.

\section{Podzial Na Poziomie wojewódzTw}

Według kryteriów zatwierdzonych przez Ministra Kultury i Dziedzictwa Narodowego dotacja dzielona jest dla województw według kryterium demograficznego ( $1 / 3$ kwoty) i czytelniczego ( $2 / 3$ kwoty; przyjęto odmienny niż na poziomie krajowym wskaźnik - czytelnicy na 100 mieszkańców). Do 2011 r. wydzielano również kwotę na dotację wyrównawczą (dla województw o niskim PKB) oraz rezerwę, z której przyznawano specjalne fundusze na podstawie złożonych wniosków dla bibliotek w szczególnie trudnych warunkach, np. z powodów losowych (pożar, zalanie, wypadek budowlany). W sytuacjach tych o przyznaniu dotacji z rezerwy i jej wysokości decydował Zespól Sterujący. Obecnie nie jest stosowana formuła wydzielania rezerwy z ogólnej puli środków, przyznaje się natomiast 5\% wartości dotacji dla każdego województwa, z której przydzielane są fundusze dla terenowych bibliotek według potrzeb uznanych przez wojewódzkie biblioteki publiczne za istotne.

\section{PODZIAE W OBRĘBIE WOJEWÓDZTW}

Dla bibliotek na terenie województwa stosowane są podobne kryteria jak w podziale dla całych województw, tzn. kryterium demograficzne 1/3 kwoty, kryterium czytelnicze - 2/3 kwoty. Do 2011 r. obowiązywały także podobne zasady podziału dotacji wyrównawczych w województwach o niskim PKB oraz możliwość uzyskania środków $\mathrm{z}$ rezerwy. Obecnie obowiązuje zasada podziału środków $\mathrm{w}$ obrębie przyznanych województwu kwot 5\%. W województwach opracowywane są także kryteria indywidualne, stosowane dla regionu. Wśród nich stosuje się np. wsparcie bibliotek:

- aktywnych, skutecznie aplikujących do programów adresowanych do instytucji kultury, zwłaszcza bibliotek, które realizowały zadania infrastrukturalne związane $\mathrm{z}$ budową, rozbudową, modernizacją i wyposażeniem obiektów. Inwestycje te stanowiły duże obciążenie dla organizatora, dodatkowe środki to promowanie aktywnych samorządów;

- realizujących duże przedsięwzięcia infrastrukturalne łączące się z uzupełnianiem i wzbogacaniem zbiorów, pełniących zadania 
ponadlokalne oraz wyróżniających się w działalności kulturalno-społecznej i dbałości o rozwój sieci na terenie gmin;

- usytuowanych w zreorganizowanej sieci (powołanie nowych filii, likwidacja placówek, zawieszenie działalności);

- aktywnie realizujących funkcje ponadlokalne, promujących czytelnictwo w lokalnym środowisku;

- otrzymujących wysokie dofinansowanie zakupu nowości z dotacji organizatora, co rejestrowane jest poprzez wzrost poziomu wskaźnika zakupu na 100 mieszkańców.

\section{REgULAMIN}

Biblioteki publiczne mogą kupować każdą publikację, która ukazała się drukiem lub na innym nośniku (książki mówione, w alfabecie Braille’a, książki elektroniczne, wydawnictwa multimedialne, nutowe i kartograficzne), dostępne na rynku księgarskim, niezależnie, czy jest to pierwsze wydanie czy wznowienie, a także niezależnie od roku wydania. Ze środków dotacji nie można kupować czasopism, które ukazują się częściej niż raz w miesiącu, programów i gier komputerowych, filmów i nagrań muzycznych, dokumentów ikonograficznych, kolekcji historycznych pozyskiwanych od osób prywatnych lub z innych instytucji, a także książek i innych dokumentów dostępnych na rynku antykwarycznym. $Z$ dotacji nie można opłacać licencji, dostępu do baz.

\section{Podsumowanie}

Program zakupu nowości wydawniczych do bibliotek jest jednym z najdłużej funkcjonujących programów skierowanych do bibliotek publicznych. Oprócz waloru trwałości i systematyczności w dofinansowywaniu bibliotek publicznych jego atutem jest współwystępowanie $\mathrm{z}$ innymi programami (np.: budowa i aranżacja obiektów, komputeryzacja, rozwój form pracy), co powoduje, iż są one instytucjami wspomaganymi systemowo, modernizowanymi i unowocześnianymi według przyjętej koncepcji. Walorem programu jest także współpraca $z$ samorządami, organizatorami bibliotek w zakresie zasad finansowania zakupów nowości do bibliotek publicznych, którzy je zaakceptowali i stosują, bowiem uznali, że biblioteki bez nowoczesnych księgozbiorów nie są atrakcyjnymi instytucjami. Wieloletni program zakupu nowości dał też szansę polskim bibliotekom zbliżenia 
warunków pracy i oferty księgozbiorowej do zalecanych norm związanych z wymianą księgozbioru, czy poziomem zakupu ${ }^{25}$.

O wymiernych korzyściach programu świadczą też wskaźniki ilustrujące wyniki pracy bibliotek publicznych:

- wzrósł zakup książek w wol. /100 mieszkańców;

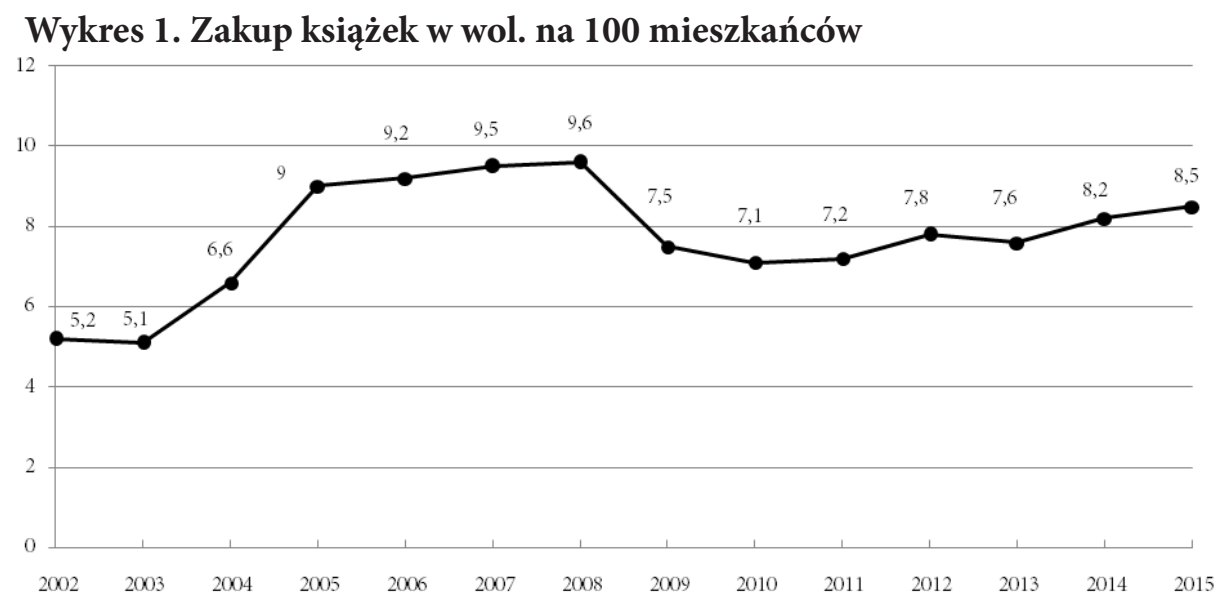

Źródło: Biblioteki Publiczne w Liczbach. Oprac. BN.

- wzrósł procentowy udział nowych książek w ogółem księgozbiorów bibliotek publicznych - lepszy wynik mają środowiska wiejskie, osiągnięty został cel wspierania środowisk małych, bibliotek działających na terenach wiejskich;

Tabela 5. Procentowy udział nowych książek w ogółem księgozbiorów

\begin{tabular}{|c|c|c|c|}
\hline \multirow{2}{*}{ Lata } & \multicolumn{3}{|c|}{ Odsetek nowych książek w ogółem księgozbiorów } \\
\cline { 2 - 4 } & ogółem & miasto & wieś \\
\hline 2002 & 1,5 & 1,6 & 1,3 \\
\hline 2006 & 2,6 & 2,7 & 2,5 \\
\hline 2010 & 2 & 2,1 & 2 \\
\hline 2013 & 2,2 & 2,2 & 2,3 \\
\hline 2014 & 2,4 & 2,3 & 2,5 \\
\hline 2015 & 2,5 & 2,5 & 2,6 \\
\hline
\end{tabular}

Zródło: Biblioteki Publiczne w Liczbach. Oprac. BN.

25 B. Budyńska, M. Jezierska: Zbiory $w$ bibliotekach publicznych a ich finansowanie, dz. cyt. 
- samorządy są angażowane do udziału w programie poprzez deklarowanie i realizowanie wkładu własnego. Blisko 100\% bibliotek przekracza minimalny wymagany wkład własny, a około $80 \%$ przekracza planowany wkład własny;

Tabela 6. Udział bibliotek w programie a wymagany wkład własny

\begin{tabular}{|c|c|c|c|c|c|}
\hline \multirow{2}{*}{ Rok } & \multirow{2}{*}{$\begin{array}{c}\text { Liczba } \\
\text { biblio- } \\
\text { tek }\end{array}$} & \multicolumn{2}{|c|}{$\begin{array}{c}\text { Biblioteki, które prze- } \\
\text { kroczyly minimalny wy- } \\
\text { magany wklad wlasny }\end{array}$} & $\begin{array}{c}\text { Biblioteki, które przekro- } \\
\text { czyly planowany wklad } \\
\text { wlasny }\end{array}$ \\
\cline { 3 - 6 } & liczba & $\mathbf{\%}$ & liczba & \% \\
\hline 2010 & 2433 & brak danych & - & brak danych & - \\
\hline 2011 & 2455 & 2455 & 100 & 1993 & 81,2 \\
\hline 2012 & 2460 & 2453 & 99,7 & 2017 & 82,4 \\
\hline 2013 & 2471 & 2464 & 99,7 & 2002 & 81 \\
\hline $2014-\mathrm{P} 1$ & 2487 & 2479 & 99,7 & 2044 & 82,2 \\
\hline $2014-\mathrm{P} 2$ & 416 & 297 & 71,4 & 236 & 56,7 \\
\hline 2015 & 2495 & 2490 & 99,8 & 2040 & 81,8 \\
\hline 2016 & 2503 & 2470 & 98,7 & 1992 & 79,6 \\
\hline
\end{tabular}

Zródło: opracowanie własne na podstawie sprawozdań wbp z realizacji zadania przygotowanych dla BN.

- rosną wydatki na zakup nowości do bibliotek publicznych przy zachowaniu większego wkładu samorządów, organizatorów bibliotek, w budowanie kolekcji bibliotecznych. Dotacje pozabudżetowe ustabilizowały się na poziomie 1/3 całości wydatków.

Tabela 7. Struktura źródeł finansowania zakupu zbiorów w latach 2002$-2015$

\begin{tabular}{|c|c|c|c|c|}
\hline \multirow{2}{*}{ Rok } & \multicolumn{4}{|c|}{ Źródła zakupu } \\
\cline { 2 - 5 } & \multicolumn{2}{|c|}{ w zl } & \multicolumn{2}{c|}{ w \% } \\
\cline { 2 - 5 } & organizator & MKiDN & organizator & MKiDN \\
\hline 2002 & 40468815 & 1150000 & 97,2 & 2,8 \\
\hline 2006 & 43955176 & 28500000 & 60,7 & 39,3 \\
\hline 2010 & 52833182 & 10000000 & 84,1 & 15,9 \\
\hline 2013 & 53800435 & 20000000 & 72,9 & 27,1 \\
\hline 2014 & 48952982 & 23000000 & 68 & 32 \\
\hline 2015 & 51509057 & 25000000 & 67,3 & 32,7 \\
\hline
\end{tabular}

Zródło: Biblioteki Publiczne w Liczbach 2002-2015. Oprac. BN. 
Podsumowanie programu zakupu nowości wydawniczych do bibliotek publicznych nie może pominąć aspektu zbyt małego wzrostu czytelnictwa $\mathrm{w}$ porównaniu $\mathrm{z}$ poniesionymi nakładami na ten cel. Dlatego należy podkreślić fakt, iż poziom czytelnictwa zależy od wielu czynników, a wzrost zakupu nowości nie jest jedynym i wystarczającym czynnikiem wpływającym na ten stan. Ważna staje się atrakcyjność lokalu zachęcająca do odwiedzania biblioteki, jak i użyteczność zasobów informacyjnych. Biblioteki muszą się rozwijać w różnych kierunkach, muszą być dotowane na takim poziomie, aby utrzymywać już wypracowany poziom zainteresowania swoimi usługami i dążyć do systematycznego, i trwałego wzrostu czytelnictwa.

\section{Bibliografia}

1. Biblioteki Publiczne w Liczbach za lata 2000-2011. Warszawa 2001-2015.

2. Budyńska B., Jezierska M.: Polityka biblioteczna i finansowanie bibliotek publicznych w Polsce. „Kultura Współczesna” 2012, nr 2, s. 122-137.

1. Budyńska B., Jezierska M.: Stan bibliotek w Polsce. Raport 2012. Warszawa 2016.

2. Budyńska B., Jezierska M.: Udział BN w realizacji rządowego programu „Promocja Czytelnictwa”. „Biuletyn Informacyjny Biblioteki Narodowej” 2006, nr 4, s. 67-72.

3. Budyńska B., Jezierska M.: Zbiory w bibliotekach publicznych a ich finansowanie (maszynopis).

4. Budyńska B., Jezierska M., Lewandowicz-Nosal G., Walczewska-Klimczak G.: Biblioteki w Polsce w 2012 r. Warszawa 2016. Tryb dostępu: http://ksiegarnia. bn.org.pl/396/Biblioteki-w-Polsce-w-2012-roku.html [29 marca 2017].

5. Kultura a rozwój. Red. J. Hausner, A. Karwińska, J. Purchla. Warszawa 2013.

6. Narodowy Program Kultury. Promocja Czytelnictwa i Rozwój Sektora na lata 2004-2013. Tryb dostępu: http://bip.mkidn.gov.pl/media/docs/NPK_Czytelnictwo.pdf [14 lipca 2017].

7. Narodowy Program Rozwoju Czytelnictwa 2014-2020. Tryb dostępu: http:// www.mkidn.gov.pl/media/docs/2013/20131220__NPRCZ.pdf [14 lipca 2017].

8. Obwieszczenie Marszałka Sejmu Rzeczypospolitej Polskiej z dnia 21 czerwca 2013 r. w sprawie ogłoszenia jednolitego tekstu ustawy o finansach publicznych. Dz.U. 2013, poz. 885.

9. Program Wieloletni Narodowy Program Rozwoju Czytelnictwa. Tryb dostępu: http://bip.mkidn.gov.pl/media/download_gallery/20150618_zalacznik_do_ projektu_uchwaly.pdf [14 lipca2017].

10. Stan bibliotek $w$ Polsce. Raport 2012. Warszawa 2016.

11. Uchwała nr 157 Rady Ministrów z dnia 25 września 2012 r. w sprawie przyjęcia Strategii Rozwoju Kraju 2020. M.P. 2012, poz. 882.

12. Uchwała Nr 61 Rady Ministrów z dnia 26 marca 2013 r. w sprawie przyjęcia Strategii Rozwoju Kapitału Społecznego 2020. Tryb dostępu: http://:isip.sejm. gov.pl/Download?id=WMP20130000378\&type=2 [14 lipca 2017]. 
13. Ustawa $z$ dnia 13 października 1998 r. Przepisy wprowadzajace ustawy reformujące administrację publiczną. Dz.U. 1998, nr 133, poz. 872.

14. Ustawa $z$ dnia 17 maja 1990 r. o podziale zadań i kompetencji określonych $w$ ustawach szczególnych pomiędzy organy gminy a organy administracji rządowej oraz o zmianie niektórych ustaw. Dz.U. 1990, nr 34, poz. 198.

15. Ustawa z dnia 24 lipca 1998 r. o zmianie niektórych ustaw określających kompetencje organów administracji publicznej - w związu z reforma ustrojowa państwa. Dz.U. 1998, nr 106, poz. 668.

16. Ustawa $z$ dnia 25 października 1991 r. o organizowaniu i prowadzeniu działalności kulturalnej. Dz.U. 1997, nr 110, poz. 721 z późn. zm.

17. Ustawa z dnia 27 czerwca 1997 r. o bibliotekach. Dz.U. 1997, nr 87, poz. 642.

18. Ustawa $z$ dnia 27 sierpnia 2009 r. o finansach publicznych. Dz.U. 2009, nr 157, poz. 1240.

19. Ustawa $z$ dnia 31 sierpnia 2011 r. o zmianie ustawy o organizowaniu i prowadzeniu działalności kulturalnej. Dz.U. 2011, nr 207, poz. 1230.

20. Ustawa $z$ dnia 5 czerwca 1998 r. o samorzadzie powiatowym. Dz.U. 1998, nr 91, poz. 578.

21. Ustawa z dnia 5 czerwca 1998 r. o samorządzie województwa Dz.U. 1998, nr 91, poz. 576.

22. Ustawa $z$ dnia 8 marca 1990 r. o samorządzie gminnym. Dz.U. 1990, nr 16, poz. 95, z późn. zm. 